\author{
Д.О. Тимченко ${ }^{1}$ Н.П. Корогод ${ }^{1}$, Т.С. Новородовська ${ }^{1}$ \\ ${ }^{1}$ Національна металургійна академія України
}

\title{
ПРАКТИЧНА РЕАЛІЗАЦІЯ ПРОЕКТУ СТВОРЕННЯ ОФІСУ ТРАНСФЕРУ ТЕХНОЛОГІЙ У ЗАКЛАДІ ВИЩОЇ ОСВІТИ
}

\begin{abstract}
На сьогоднішній день ефективне функціонування закладів вищої освіти (ЗВО) можливе лише за умови залучення до співпраці представників бізнесу. 3 метою налагодження такої співпраці пропонується створення окремої організаційної структури у 3ВО - офісу трансферу технологій (ОТТ), що по суті являє собою проект, для успішної реалізації якого необхідно застосування методології управління проектами. У результаті проведення дослідження питання управління проектом створення ОТТ у ЗВО автором були запропоновані: концептуальна модель управління проектом створення ОТТ у ЗВО та метод створення ОТТ у ЗВО з елементами дизайн-мислення, які під час реалізації проекту дозволяють врахувати водночас специфіку ЗВО та потреби стейкхолдерів. У даній статті присвячена увага питанням практичної реалізації запропонованих моделей і методів управління проектом створення ОТТ у ЗВО на прикладі Національної металургійної академії України (НМетАУ).
\end{abstract}

DOI: $0543-5749.2020-2-62-73$

\section{Вступ}

У ході досліджень було встановлено, що відповідно до сучасного вектору політики держави щодо інноваційної діяльності та трансферу технологій, відповідно якому ЗВО можуть самостійно розробляти та впроваджувати програми науково-технічної та інноваційної діяльності, формувати інноваційні структури задля поєднання інтересів науки, освіти, бізнесу та держави 3 метою виконання і впровадження інноваційних проектів, а також самостійно визначати статті та обсяги витрат власних надходжень, реалізація проекту ОТТ у ЗВО стає не лише можливою, а й необхідною [1].

Про спрямованість державної політики на розбудову інноваційної екосистеми в Україні свідчить наступне [2]. Місія Міністерства освіти і науки України (МОН) полягає у розробленні і здійсненні державної політики, що гарантує розвиток науки як джерела економічного зростання, створення умов для реалізації інтелектуального потенціалу громадян у сфері наукової і науково-технічної діяльності, забезпечення використання досягнень вітчизняної та світової науки і техніки для задоволення соціальних, економічних, культурних та інших потреб [3].

Стратегічний план МОН до 2024 р. одним iз пріоритетів визначає розвиток інновацій 3 метою створення та впровадження розробок, що, окрім доступу до фінансових ресурсів, передбачає наявність відповідної інфраструктури. Показники результативності: динаміка обсягу фінансування інноваційної діяльності; динаміка обсягу реалізованої інноваційної продукції; кількість укладених договорів про трансфер технологій; обсяг державних коштів, спрямованих на розвиток інноваційної інфраструктури; місце України за рейтингом Human capital index [3].

МОН наголошує на необхідності сприяння розвитку регіональних інноваційних структур 3 функцією трансферу технологій і покладає на керівників ЗВО завдання забезпечення ефективного управління інноваційною діяльністю.

Згідно Оперативному плану МОН вже на 2020 р. передбачається: реалізація 3ВО усіх видів автономії, передусім фінансової; забезпечення керівниками ЗВО ефективного управ-

(C) Тимченко Д.О., Корогод Н.П., Новородовська Т.С., 2020 
ління інноваційною діяльністю; створення структур, які забезпечують впровадження розробок інноваторами; сприяння держави залученню приватних інвестицій у науку та інновації (R\&D\&I); долучення України до міжнародних наукових програм та організацій; запровадження грантового фінансування науки; запровадження податкових стимулів для інвесторів наукової діяльності та благодійників, скасування оподаткування іноземних грантів [4].

Водночас політика НМетАУ також спрямована на налагодження зв'язків 3 представниками бізнесу. Так, у стратегічному плані НМетАУ передбачається: більш активна співпраця 3 металургійними, машинобудівними та іншими підприємствами; підтримка і просування на ринок та реалізація наукових розробок, нової техніки i новітніх технологій, створених в НМетАУ; сприяння виконанню науководослідницьких робіт за рахунок позабюджетних коштів; залучення вчених до співпраці у виконанні науково-технічних завдань промисловості [5].

I хоча безпосередньо у Стратегічному плані НМетАУ створення інноваційної інфраструктури для активізації співпраці з представниками бізнесу не передбачено, іншого механізму реалізації поставленого завдання не існує. Адже ефективне управління даним процесом можливе лише за наявності окремого підрозділу - ОТТ, який здійснюватиме управління проектами трансферу технологій.

Мета дослідження полягає в обгрунтуванні необхідності створення ОТТ у ЗВО, зокрема в НМетАУ, а також в описі основних етапів практичної реалізації проекту створення ОТТ у НМетАУ на основі запропонованих автором моделей та методів управління таким проектом.

\section{Методика}

Під час проведення дослідження був використаний концептуальний підхід, який передбачає попереднє розроблення концепції дослідження, тобто комплекс ключових положень, які визначають загальну спрямованість та послідовність дослідження [6]. Даний підхід полягає в активізації підтримки діючих форм інтеграції та формування нових перспективних варіантів організації взаємодії науки, вищої освіти i виробництва шляхом здійснення комплексу за- ходів 3 метою переходу від стихійного стану до планового [7].

Концептуальна модель управління проектом створення ОТТ у ЗВО враховує специфіку функціонування ЗВО та включає сім етапів, серед яких: налаштування психологічного клімату, ініціювання, затвердження, планування, виконання, моніторинг і контроль, етап завершення - створений ОТТ у ЗВО [8].

Також в основу проведення дослідження був покладений метод дизайн-мислення, суть якого полягає у створенні продуктів та послуг, орієнтованих на людину. Під час даного процесу дослідники намагаються зрозуміти користувача та його проблеми, роблять і перевіряють припущення, змінюють постановку проблеми, намагаються знайти альтернативні стратегії та рішення [9].

Метод створення ОТТ у ЗВО з елементами дизайн-мислення передбачає визначення потреб та зацікавленості стейкхолдерів проекту у налагодженні співпраці між представниками ЗВО та бізнесу та створення продукту проекту з урахуванням виявлених потреб. Реалізація даного методу передбачає застосування інструментів дизайн-мислення, серед яких опитування та спостереження.

\section{Результати та їх обговорення}

Запропоновані концептуальна модель створення ОТТ у ЗВО та метод створення ОТТ у ЗВО $з$ елементами дизайн-мислення передбачають проведення підготовчого етапу створення ОТТ, а саме проведення спостережень та опитувань серед співробітників НМетАУ та представників бізнесу, які мають відношення до впровадження інновацій у металургійній галузі.

Під час проведення спостережень було встановлено, що окрім підтримки з боку держави створення функціональних підрозділів, що здійснюватимуть управління проектами трансферу технологій у ЗВО - ОТТ, про необхідність запровадження такої структури свідчать також статистичні дані, отримані автором на основі підрахунку зареєстрованих у відношенні НMетАУ об'єктів права інтелектуальної власності (ОПІВ). Так, згідно базі даних (БД) "Спеціальна інформаційна система Укрпатенту" станом на квітень 2020 року всього НМетАУ є власником 527 патентів України, 3 яких діють лише $40-$ рисунок 1 [10]. 
300

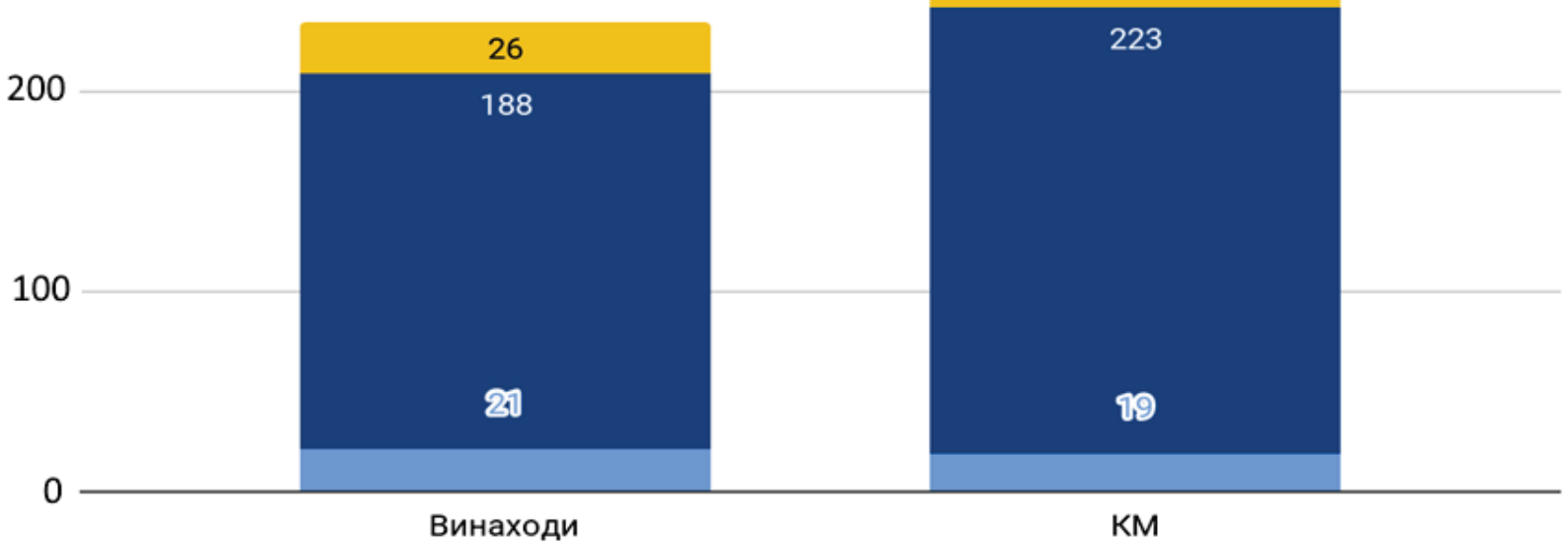

Рис. 2. Кількість патентів НМетАУ станом на квітень 2020 р.

Пропонуємо визначити коефіцієнт корисної дії - в даному випадку характеристику ефективності системи інноваційної діяльності НМетАУ. Для розрахунку використаємо відношення чинних патентів НМетАУ до їх сумарної кількості. В результаті отримаємо величину, виражену у процентах:

$$
\eta=A / Q,
$$

де $\eta$ - коефіцієнт корисної дії; $A$ - кількість чинних патентів НМетАУ; $Q-$ загальна кількість патентів НМетАУ.

Таким чином, у підсумку коефіцієнт корисної дії у відношенні інноваційної діяльності НМетАУ становить 7,6 \%.

Статистичні дані за останні 10 років щодо винаходів наведені у таблиці 1.

Таблиця 1. Кількість патентів України на винаходи, власник - НМетАУ станом на квітень 2020 р.

\begin{tabular}{|c|c|c|c|c|}
\hline $\begin{array}{c}\text { Патенти } \\
\text { на винаходи }\end{array}$ & Діють & Не діють & $\begin{array}{c}\text { Дія може бути } \\
\text { припинена }\end{array}$ & Всього \\
\hline 2020 & 4 & 0 & 4 & 8 \\
\hline 2019 & 9 & 0 & 1 & 10 \\
\hline 2018 & 1 & 0 & 10 & 14 \\
\hline 2017 & 0 & 4 & 4 & 18 \\
\hline 2016 & 0 & 14 & 0 & 21 \\
\hline 2015 & 1 & 12 & 0 & 9 \\
\hline 2014 & 0 & 21 & 0 & 16 \\
\hline 2013 & 0 & 9 & 1 & 11 \\
\hline 2012 & 0 & 15 & 0 & 16 \\
\hline 2011 & 0 & 11 & 0 & \\
\hline 2010 & 0 & 16 & & \\
\hline
\end{tabular}

Таким чином, за останні 10 років НМетАУ стала власником 150 патентів України на винаходи, з яких діють лише 15.
Статистичні дані за останні 10 років щодо корисних моделей наведені у таблиці 2. 
Таблиця 2. Кількість патентів України на корисні моделі, власник - НМетАУ, станом на квітень 2020 р.

\begin{tabular}{|c|c|c|c|c|}
\hline Патенти на КМ & Діють & Не діють & $\begin{array}{c}\text { Дія може бути } \\
\text { припинена }\end{array}$ & Всього \\
\hline 2020 & 0 & 0 & 2 & 2 \\
\hline 2019 & 8 & 0 & 5 & 13 \\
\hline 2018 & 5 & 0 & 26 & 31 \\
\hline 2017 & 1 & 5 & 13 & 19 \\
\hline 2016 & 1 & 15 & 4 & 20 \\
\hline 2015 & 0 & 18 & 3 & 21 \\
\hline 2014 & 0 & 20 & 0 & 20 \\
\hline 2013 & 0 & 25 & 0 & 25 \\
\hline 2012 & 0 & 18 & 0 & 18 \\
\hline 2011 & 0 & 29 & 0 & 29 \\
\hline 2010 & 0 & 18 & 0 & 18 \\
\hline
\end{tabular}

Таким чином, за останні 10 років НМетАУ стала власником 216 патентів України на корисні моделі, з яких діють лише 15.

Разом коефіцієнт корисної дії у відношенні інноваційної діяльності НМетАУ за останні 10 років становить $8,2 \%$.

Вищенаведені дані свідчать про відсутність необхідності підтримувати чинність патентів. Під час проведення опитувань серед співробітників ЗВО були визначені фактори, що впливають на відсутність такої необхідності, серед яких:

1. Патент не має цінності (кількість патентів враховується при складаннях рейтингів 3ВО, викладачів та при захисті дисертаційних робіт, тому деякі патенти реєструються для кількості і їхнє впровадження у реальний сектор економіки не передбачалось).

2. Винахідники не знають дійсну цінність запатентованої розробки та не знають до кого звернутися з пропозицією про надання ліцензії або передачу прав на патент.

3. Винахідники можливо і зверталися до безпосередньо тих підприємств, які можуть бути зацікавлені у розробці, або представляли іiі на конференціях, виставках, проте не зацікавили представників бізнесу.

4. ЗВО дорого підтримувати чинність патентів, адже за підтримку чинності необхідно сплачувати державний збір, сума якого щороку зростає.

5. Технічне рішення, вирішення якого передбачається патентом, не відповідає сучасним вимогам та потребам ринку.

3 огляду на вищезазначене НМетАУ, напе- вно як і велика кількість інших 3ВО, здійснює більшість досліджень та інноваційних розробок на замовлення певних підприємств, а тому всі отримані результати передаються їм без реєстрації ОПІВ у відношенні НМетАУ. Здебільшого дані розробки реєструє на себе безпосередньо підприємство-замовник, а НМетАУ таким чином залишається не зазначеним у патентах i втрачає свою інтелектуальну власність, разом 3 якою - можливість отримувати відрахування за ліцензійними договорами. Водночас фінансування проведення досліджень у НМетАУ щороку зростає - рис. 2. [11 - 13].

Зважаючи на потенціал НМетАУ, яка посідає 15 місце у рейтингу ЗВО "Топ-200 Україна" за 2018 - 2019 роки [14], перспективність досліджень у металургійному напрямку, фокусуванні Дніпропетровської області, яка також $є$ однією із провідних промислово розвинених областей України, на дослідженнях у галузі технічних наук та водночас не затребуваність більшості існуючих наразі технологій НМетАУ, не відповідність їх потребам ринку, слаборозвинену співпрацю 3 представниками бізнесу, необхідність збільшення обсягів позабюджетного фінансування - реалізація проекту створення ОТТ є обов'язковим та першочерговим завданням.

Таким чином, у результаті спостережень та проведених серед співробітників функціональних підрозділів НМетАУ опитувань була підтверджена необхідність створення окремого структурного підрозділу - ОТТ, головне завдання якого полягає у реалізації проектів та портфелів проектів трансферу технологій. 


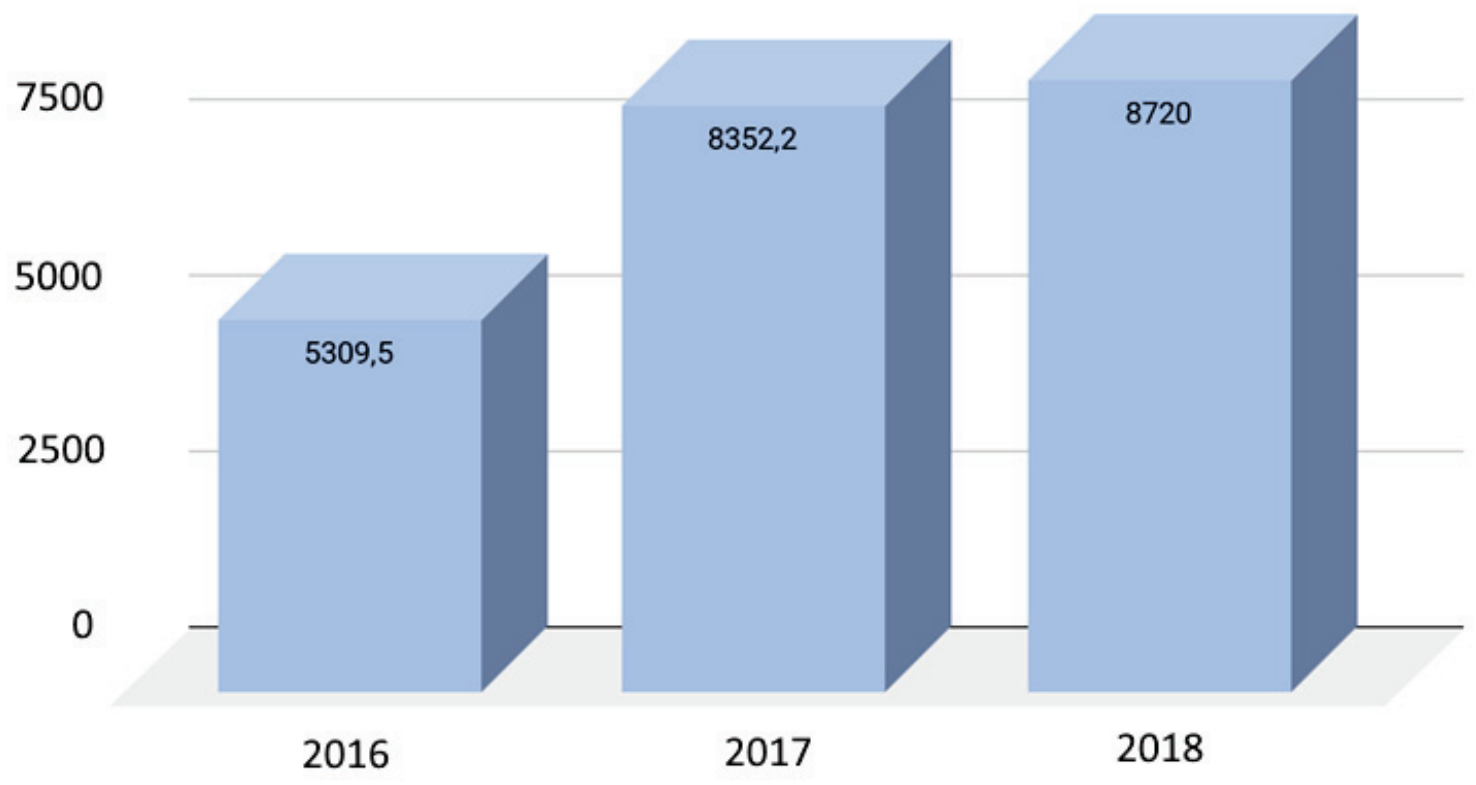

Рис. 2. Обсяг фінансування досліджень у НМетАУ, у тис. грн.

Таким чином, у результаті спостережень та проведених серед співробітників функціональних підрозділів НМетАУ опитувань була підтверджена необхідність створення окремого структурного підрозділу - ОТТ, головне завдання якого полягає у реалізації проектів та портфелів проектів трансферу технологій.

Зважаючи на потенціал НМетАУ, яка посідає 15 місце у рейтингу ЗВО "Топ-200 Україна" за 2018 - 2019 роки [14], перспективність досліджень у металургійному напрямку, фокусуванні Дніпропетровської області, яка також є однією із провідних промислово розвинених областей України, на дослідженнях у галузі технічних наук та водночас не затребуваність більшості існуючих наразі технологій НМетАУ, не відповідність їх потребам ринку, слаборозвинену співпрацю $з$ представниками бізнесу, необхідність збільшення обсягів позабюджетного фінансування - реалізація проекту створення ОТТ є обов'язковим та першочерговим завданням.

Таким чином, у результаті спостережень та проведених серед співробітників функціональних підрозділів НМетАУ опитувань була підтверджена необхідність створення окремого структурного підрозділу- ОТТ, головне завдання якого полягає у реалізації проектів та портфелів проектів трансферу технологій.
Через особливості функціонування ЗВО, серед яких можна виділити занадто бюрократизовані процедури, несхильність співробітників до ризику, страх взяти на себе відповідальність, процес впровадження змін повинен бути поступовим. При цьому в обов'язковому порядку до всіх співробітників мають бути доведені (бажано неформальними каналами) конкретні причини впровадження змін та очікувані позитивні наслідки такого впровадження. Налаштування психологічного клімату у ЗВО може зайняти тривалий час, водночас це дозволить сприйняти зміни, спричинені необхідністю створення нової організаційної структури.

Наступним етапом $\epsilon$ ініціювання проекту створення ОТТ у ЗВО - основні положення Заявки на розгляд ініціативи викладено в таблиці 3.

Одним із завдань, що постають на етапі ініціювання проекту створення ОТТ у ЗВО є визначення стейкхолдерів проекту - рисунок 3 .

Після погодження та затвердження Заявки на розгляд ініціативи автором даного дослідження був розроблений Статут проекту, у якому були визначені цілі проекту, заходи для досягнення поставлених цілей та очікуваний результат. В основу створення Статуту проекту були покладені положення Заявки на розгляд ініціативи. 
Таблиця 3. Основні положення Заявки на розгляд ініціативи

\begin{tabular}{|c|}
\hline 1. Назва ініціативи \\
\hline Створення офісу трансферу технологій (ОТТ) у НМетАУ \\
\hline 2. Формулювання проблеми \\
\hline $\begin{array}{l}\text { Велика кількість технологій, розробок та ОПІВ НМетАУ залишаються не затребуваними. } \\
\text { Велика кількість технологій, розробок та ОПІВ НМетАУ не відповідають потребам ринку. } \\
\text { Слабо розвинена співпраця НМетАУ з представниками бізнесу. } \\
\text { Необхідність збільшення обсягів позабюджетного фінансування }\end{array}$ \\
\hline 3. Мета проекту \\
\hline $\begin{array}{l}\text { Запровадження та налагодження роботи ОТТ в НМетАУ з метою реалізації проектів та портфелів } \\
\text { проектів трансферу технологій }\end{array}$ \\
\hline 4. Підстави для ініціювання проекту \\
\hline $\begin{array}{l}\text { 4.1. Відповідність стратегічному плану МОН до } 2024 \text { р. } \\
\text { 4.2. Відповідність оперативному плану МОН на } 2020 \text { р. } \\
\text { 4.3. Відповідність стратегічному плану НМетАУ. } \\
\text { 4.4. Відповідність потребам стейкхолдерів проекту. }\end{array}$ \\
\hline 5. Опис ініціативи \\
\hline $\begin{array}{l}\text { Ключові цілі проекту: } \\
\text { 1) створення структурного підрозділу - ОТТ; } \\
\text { 2) впровадження єдиної політики задля налагодження процесів створення інтелектуальної власності } \\
\text { та трансферу технологій; } \\
\text { 3) розповсюдження інформації про інтелектуальну власність та трансфер технологій з метою залу- } \\
\text { чення всіх зацікавлених осіб НМетАУ до співпраці; } \\
\text { 4) створення та ведення єдиної БД всіх технологій, розробок та ОПІВ НМетАУ; } \\
\text { 5) створення юзабіліті розділу сайту НМетАУ, присвяченого технологіям, розробкам та ОПІВ; } \\
\text { 6) просування технологій, розробок та ОПІВ НМетАУ; } \\
\text { 7) визначення та налагодження співпраці з потенційно зацікавленими у технологіях, розробках та } \\
\text { ОПІВ НМетАУ представниками бізнесу; } \\
\text { 8) навчання навичкам методології управління проектами функціональних керівників НМетАУ; } \\
\text { 9) управління проектами та портфелями проектів трансферу технологій. }\end{array}$ \\
\hline 6. Очікувані результати реалізації ініціативи \\
\hline $\begin{array}{l}\text { Створення ОТТ, оцінка його відповідності потребам стейкхолдерів. } \\
\text { Створення юзабіліті розділу сайту НМетАУ, присвяченого технологіям, розробкам та ОПІВ з метою } \\
\text { налагодження комунікаціних каналів з представниками бізнесу, оцінка його відповідності потребам } \\
\text { стейкхолдерів. } \\
\text { Збільшення обсягів позабюджетного фінансування }\end{array}$ \\
\hline
\end{tabular}




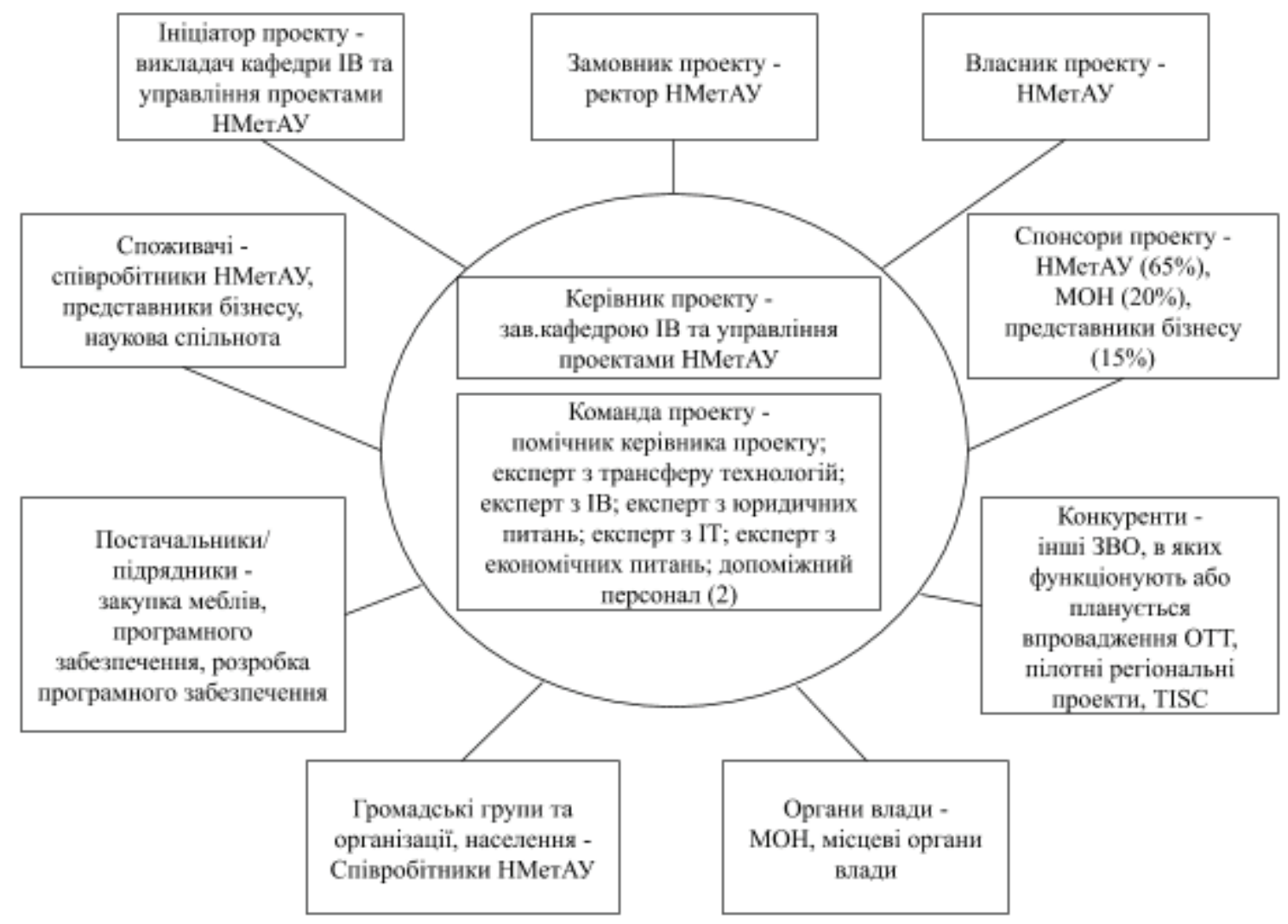

Рис. 3. Стейкхолдери проекту створення ОТТ у НМетАУ

Після розгляду, погодження та затвердження Статуту проекту було розпочато планування проекту створення ОТТ у ЗВО шляхом розробки Базового плану проекту, в основу якого покладено положення Статуту проекту. Наступною стадією після планування відповідно концептуальній моделі створення ОТТ у ЗВО є виконання проекту, яке має здійснюватись у відповідності з Базовим планом проекту. Під час моніторингу і контролю проекту визначається відповідність виконання такого проекту встановленим згідно Базовому плану проекту, а також потребам стейкхолдерів. Таким чином, у результаті реалізації проекту був створений ОТТ у НМетАУ.

Реалізація проекту була запланована - 3 травня 2019 року по вересень 2020 року. Фактично у травні 2020 року був створений прототип OTT. У вересні за результатами оцінки його діяльності було прийнято рішення про початок функціонування ОТТ у НМетАУ. Під час реалізації проекту передбачений Базовим планом бюджет не був перевищений. Відповідність створеного ОТТ потребам стейкхолдерів була визначена шляхом застосування методу відповідності створеного прототипу ОТТ потребам стейкхолдерів, суть якого полягає в анкетуванні співробітників 3ВО та визначених представників бізнесу із застосуванням в анкеті закритих запитань, що дають змогу оцінити респондентами за 10 критеріями ефективність роботи OTT. За кожним критерієм здійснюється сумарна оцінка, на основі отриманих даних будується діаграма Парето, що дасть можливість визначити напрямки вдосконалення роботи ОТТ. Визначення відповідності ОТТ потребам стейкхолдерів $\epsilon$ напрямком проведення подальшого дослідження.

Таким чином, у результаті реалізації проекту були реалізовані визначені у Статуті проекту цілі. Проект був завершений вчасно, у межах передбаченого бюджету та у відповідності до потреб стейкхолдерів.

\section{Висновки}

Аналіз проведених у ході дослідження спостережень та опитувань показав, що існує об'єктивна необхідність створення на базі 3ВО організаційної структури, що відповідатиме за налагодження співпраці 3 представниками бізнесу та впровадження науково-технічних розро- 
бок у реальний сектор економіки - ОТТ. Адже одним із напрямів підвищення конкурентоспроможності ЗВО є залучення представників бізнесу до співпраці. Спрямованість політики держави на розбудову інноваційної екосистеми в Україні також сприяє створенню ОТТ у ЗВО.

Таким чином, у даній статті була обгрунтована необхідність створення ОТТ у ЗВО, а саме у НМетАУ. Також були описані основні етапи створення ОТТ у НМетАУ на основі концептуальної моделі створення ОТТ у ЗВО, а також методу створення ОТТ у ЗВО з елементами дизайн-мислення.

За результатами проведеного дослідження можна дійти висновку, що ефективне ефективна реалізація проекту створення ОТТ у ЗВО передбачає обов'язкове застосування проектного підходу. Практична значущість наукових результатів полягає у створенні ОТТ у НметАУ вчасно, у межах передбаченого бюджету та у відповідності до потреб стейкхолдерів. Описані у даній статті результати можуть бути основою для проведення подальших досліджень у даній галузі.

\section{Бібліографічний список}

1. Закон України "Про вищу освіту" від 01.07.2014 № 1556-VII. База даних "Законодавство України" [Електронний ресурс]. Режим доступу: https://zakon.rada.gov.ua/laws/show/155618\#top (дата звернення 24.11.2019)

2. Тимченко Д.О. Проблеми створення інноваційної екосистеми в Україні. Вісник Національного технічного університету "ХПГ", серія: Стратегічне управління, управління портфелями, програмами та проектами 2002. № 2. C. 56-63.

3. Стратегічний план діяльності Міністерства освіти і науки України до 2024 р., затверджений 12.19.2019 р. [Електронний ресурс]. Режим доступу: https://bit.ly/3kuPUFy (Дата звернення 24.11.2019)

4. Оперативний план Міністерства освіти і науки на 2020 р., затверджений Наказом МОН від 27.12.2019 р. № 1640. [Електронний ресурс]. Режим доступу: https://bit.ly/3otIXXx (Дата звернення 24.11.2019)

5. Стратегічний план розвитку Національної металургійної академії України на 2019 2025 pp., затверджений Протоколом № 1 від 14.01.2019 р. Вченою радою НМетАУ. [Електронний ресурс]. Режим доступу: https://bit.ly/3otJ8Cb (Дата звернення 24.11.2019)
6. Кузьмінська, Ю.М. Моделі та методи формування команд освітніх проектів підвищення кваліфікації: автореф. дис. ... канд. техн. наук.: 05.13.22 - управління проектами та програмами. Львів: Львів. держ. ун-т безпеки життєдіяльності, 2019. $21 \mathrm{c.}$

7. Землянкін, А. І., Підоричева, І. Ю. Концептуальний підхід до інтеграції науки, вищої освіти і виробництва. Стратегія $і$ механізми регулювання промислового розвитку: зб. наук. пр. Донецьк: ІЕП НАНУ, 2009. С. 87-100.

8. Тимченко Д.О. Концептуальна модель управління проектом створення офісу трансферу технологій у закладі вищої освіти. Управління проектами: стан та перспективи: матер. XVI міжнар. науково-практична конф. (811 вересня 2020 р.). Миколаїв: Нац. університет кораблебудування імені адмірала Макарова, 2020. С. 110-113.

9. Фабрикант О. Давай по порядку: як влаштовано метод Design Thinking. [Електронний ресурс]. Режим доступу: http://bydesign.platfor.ma/stages-of-dt (Дата звернення 05.08.2020)

10. База даних "Спеціальна інформаційна система Укрпатенту". [Електронний ресурс]. Режим доступу: https://bit.ly/2J9og32 (Дата звернення 20.04.2020)

11. Звіт Національної металургійної академії України про результати виконання умов контракту, статуту, показників ефективності використання державного майна та дотримання законодавства у сфері діяльності навчального закладу ректором НМетАУ, професором Величко О.Г. у 2016 році, затверджений 23 грудня 2016 року протоколом № 2. [Електронний ресурс]. Режим доступу: https://bit.ly/3jx7RC2 (Дата звернення 17.12.2019)

12. Звіт Національної металургійної академії України про результати виконання умов контракту, статуту, показників ефективності використання державного майна, показників ефективності підготовки науково-педагогічних кадрів через аспірантуру та докторантуру, видання підручників, посібників, науковометодичної літератури та дотримання законодавства у сфері діяльності закладу вищої освіти ректором НМетАУ, професором Величко О.Г. у 2017 році, затверджений 26 грудня 2017 року протоколом № 2. [Електронний ресурс]. Режим доступу: https://bit.ly/3mmbbBG (Дата звернення 17.12.2019)

13. Звіт Національної металургійної ака- 
демії України про результати виконання умов контракту, статуту, показників ефективності використання державного майна, показників ефективності підготовки науково-педагогічних кадрів через аспірантуру та докторантуру, видання підручників, посібників, науковометодичної літератури та дотримання законодавства у сфері діяльності закладу вищої освіти ректором

НМетАУ, професором Величко О.Г. у 2018 році, затверджений 26 грудня 2018 року протоколом № 1. [Електронний ресурс]. Режим доступу: https://bit.ly/2HBBJ2K (Дата звернення 17.12.2019)

14. Інформація з сайту Громадської організації Центр міжнародних проектів "Свроосвіта". [Електронний ресурс]. Режим доступу: https://bit.ly/3dXjaSG (Дата звернення 17.12.2019)

\section{References}

1. Law of Ukraine "On Higher Education" (01.07.2014 № 1556-VII). (2014). Database "Legislation of Ukraine". Retrieved from https://zakon.rada.gov.ua/laws/show/1556-18\#top

2. Tymchenko, D. O. (2020). Problems of creating an innovative ecosystem in Ukraine, Visnyk Natsionalnoho tekhnichnoho universytetu "KhPI", series: Strategic management, portfolio, programs and projects management, (2),56-63

3. Strategic action plan of the Ministry of Education and Science of Ukraine until 2024 (Approved 12.19.2019). (2019). Retrieved from https://bit.ly/3kuPUFy

4. Operational plan of the Ministry of Education and Science for 2020. (Approved by the Order of the Ministry of Education and Science of 27.12.2019 № 1640) (2019). Retrieved from https://bit.ly/3otIXXx

5. Strategic development plan of the National Metallurgical Academy of Ukraine for 20192025, approved by Protocol № 1 of 14.01.2019 by the Academic Council of NMetAU. (2019). Retrieved from https://bit.ly/3otJ8Cb

6. Kuzminskaya, Yu. M. (2019). Models and methods of forming teams of educational projects of advanced training (Author's ref. dis.... Cand. of Tech. Sciences. 05.13.22 - Project and Program Management). Lviv State University of Life Safety, Lviv

7. Zemlyankin, A. I., Pidoricheva, I. Y. (2009). Conceptual approach to the integration of science, higher education and industry. Strategy and mechanisms for regulating industrial development (pp. 87-100). Donetsk: IEP NASU

8. Tymchenko, D. O. (2020). Conceptual model of project management for the creation of a technology transfer office in a higher education institution. Project management: status and prospects: mater. XVI International scientific and practical conference (September 8-11, 2020). Mykolaiv: Nat. Admiral Makarov Shipbuilding University, 110-113

9. Fabrykant O. Let's go in order: how the Design Thinking method is arranged. Retrieved from http://bydesign.platfor.ma/stages-of-dt

10. Ukrpatent Special Information System database. Retrieved from https://bit.ly/2J9og32

11. Report of the National Metallurgical Academy of Ukraine on the results of fulfilling the terms of the contract, charter, indicators of efficiency of use of state property and compliance with legislation in the field of activity of the educational institution by the rector of NMetAU, Professor Velychko O.G. in 2016, approved on December 23, 2016 by the protocol № 2. (2016). Retrieved from https://bit.ly/3jx7RC2

12. Report of the National Metallurgical Academy of Ukraine on the results of the contract, statute, indicators of efficiency of state property, indicators of efficiency of training of scientific and pedagogical staff through postgraduate and doctoral studies, publication of textbooks, manuals, scientific and methodological literature and compliance with legislation in the field of higher education. NMetAU, professor Velichko O.G. in 2017, approved on December 26, 2017 by the protocol № 2. (2017). Retrieved from https://bit.ly/3mmbbBG

13. Report of the National Metallurgical Academy of Ukraine on the results of the contract, statute, indicators of efficiency of state property, indicators of efficiency of training of scientific and pedagogical staff through postgraduate and doctoral studies, publication of textbooks, manuals, scientific and methodological literature and compliance with legislation in the field of higher education. NMetAU, professor Velichko $O G$ in 2018, approved on December 26, 2018 by the protocol № 1. (2018). Retrieved from https://bit.ly/2HBBJ2K

14. Information from the website of the Center for International Projects "Euroeducation" NGO. (2019). Retrieved from https://bit.ly/3dXjaSG 
Тимченко Дар'я Олександрівна, викладач кафедри інтелектуальної власності та управління проектами, Національна металургійна академія України (м. Дніпро, Україна). ORCID ID: 0000-0003-2784-883X. E-mail: dariatymchenko1@gmail.com

Корогод Наталія Петрівна, доцент, кандидат педагогічних наук, завідувач кафедрою інтелектуальної власності та управління проектами, Національна металургійна академія України (м. Дніпро, Україна). ORCID ID: 0000-0002-0242-5497. E-mail: nkorogod@gmail.com

Новородовська Тетяна Сергіївна, доцент, кандидат біологічних наук, доцент кафедри інтелектуальної власності та управління проектами, Національна металургійна академія України (м. Дніпро, Україна). ORCID ID: 0000-0002-4654-843X. E-mail: tetiana.novo@gmail.com

\section{ПРАКТИЧНА РЕАЛІЗАЦІЯ ПРОЕКТУ СТВОРЕННЯ ОФІСУ ТРАНСФЕРУ ТЕХНОЛОГІЙ У ЗАКЛАДІ ВИЩОЇ ОСВІТИ}

Мета - обгрунтування необхідності створення офісу трансферу технологій у закладі вищої освіти, зокрема в Національній металургійній академії України, а також опис основних етапів практичної реалізації проекту створення офісу трансферу технологій у Національній металургійній академії України на основі запропонованих автором моделей та методів управління таким проектом.

Методика. Під час виконання дослідження використано: концептуальну модель управління проектом створення офісу трансферу технологій у закладі вищої освіти, яка враховує специфіку функціонування закладу вищої освіти та включає сім етапів створення офісу трансферу технологій; метод створення офісу трансферу технологій у закладі вищої освіти з елементами дизайн-мислення, який передбачає визначення потреб та зацікавленості стейкхолдерів проекту у налагодженні співпраці між представниками закладу вищої освіти та бізнесу та створення продукту проекту з урахуванням виявлених потреб на основі інструментів дизайн-мислення.

Результати. Дослідження практичної реалізації проекту створення офісу трансферу технологій у закладі вищої освіти показало, що ефективність реалізації такого проекту полягає насамперед у застосуванні проектного підходу. Застосування концептуальної моделі управління проектом створення офісу трансферу технологій у закладі вищої освіти та методу створення офісу трансферу технологій у закладі вищої освіти з елементами дизайн-мислення дозволило налагодити процес створення даної організаційної структури у Національній металургійній академії України, реалізувати проект вчасно, у рамках запланованого бюджету та у відповідності до потреб стейкхолдерів.

Наукова новизна. Проведені дослідження обгрунтували необхідність створення офісу трансферу технологій у Національній металургійній академії України. Були описані основні етапи реалізації проекту створення офісу трансферу технологій у Національній металургійній академії України, визначені стейкхолдери проекту, наведені основні положення Заявки на розгляд ініціативи, яка включає цілі проекту.

Практична цінність. Описані у даній статті основні етапи проекту створення офісу трансферу технологій у Національній металургійній академії України відповідно до концептуальної моделі управління проектом створення офісу трансферу технологій у закладі вищої освіти дозволять створити таку організаційну структуру на базі будь-якого закладу вищої освіти.

Ключові слова: офіс трансферу технологій, проектний підхід, концептуальна модель управління проектом, заклад вищої освіти, впровадження технологій.

Daria Tymchenko, Teacher of the Department of Intellectual Property and Projects Management, National Metallurgical Academy of Ukraine (Dnipro, Ukraine). ORCID ID: 0000-0003-2784883X. E-mail: dariatymchenko1@gmail.com

Nataliia Korogod, Associate Professor, Candidate of Pedagogical Sciences, Head of the Department of Intellectual Property and Projects Management, National Metallurgical Academy of Ukraine (Dnipro, Ukraine). ORCID ID: 0000-0002-0242-5497. E-mail: nkorogod@gmail.com, 
Tetiana Novorodovska, Associate Professor, Candidate of Biological Sciences, Associate Professor of the Department of Intellectual Property and Projects Management, National Metallurgical Academy of Ukraine (Dnipro, Ukraine). ORCID ID: 0000-0002-4654-843X. E-mail: tetiana.novo@gmail.com

\section{PRACTICAL IMPLEMENTATION OF THE PROJECT OF CREATION OF A TECHNOLOGY TRANSFER OFFICE IN HIGHER EDUCATION INSTITUTIONS}

The purpose of the paper is to substantiate the need to create a technology transfer office in a higher educational institution, namely in the National Metallurgical Academy of Ukraine, as well as to describe the main stages of the practical implementation of the project for creating a technology transfer office in the National Metallurgical Academy of Ukraine based on the models and methods of managing such a project proposed by the author.

Methods. During the research, the following were used: a conceptual model of project management for creating a technology transfer office in a higher educational institution, which takes into account the specifics of the functioning of a higher educational institution and includes seven stages of creating a technology transfer office; a method of creating a technology transfer office in a higher educational institution with elements of design thinking, which provides for the determination of the needs and interest of project stakeholders in establishing cooperation between representatives of a higher educational institution and business and creating a project product, taking into account the identified needs using design thinking tools.

Results. The study of the practical implementation of the project for creating a technology transfer office in a higher educational institution showed that the effectiveness of the implementation of such a project lies primarily in the application of the project approach. The application of the conceptual model of project management for the creation of a technology transfer office in a higher educational institution and the method of creating a technology transfer office in a higher educational institution with elements of design thinking made it possible to establish the process of creating this organizational structure at the National Metallurgical Academy of Ukraine, to implement the project on time, within the planned budget and according to the needs of stakeholders.

Originality. The studies carried out proved the need to create a technology transfer office at the National Metallurgical Academy of Ukraine. The main stages of the implementation of the project for the creation of a technology transfer office at the National Metallurgical Academy of Ukraine were described, the stakeholders of the project were identified, the main provisions of the Application for consideration of the initiative, which includes the goals of the project, were given.

Practical implications. The main stages of the project for creating a technology transfer office at the National Metallurgical Academy of Ukraine, described in this article, in accordance with the conceptual model of project management for creating a technology transfer office at a higher educational institution, will make it possible to create such an organizational structure on the basis of any higher educational institution.

Keywords: technology transfer office, project approach, conceptual model of project management, higher educational institution, technology implementation.

Тимченко Дарья Александровна, преподаватель кафедры интеллектуальной собственности и управления проектами, Национальная металлургическая академия Украины (г. Днепр, Украина). ORCID ID: 0000-0003-2784-883X. E-mail: dariatymchenko1@gmail.com

Корогод Наталия Петровна, доцент, кандидат педагогических наук, заведующая кафедрой интеллектуальной собственности и управления проектами, Национальная металлургическая академия Украины (г. Днепр, Украина). ORCID ID: 0000-0002-0242-5497. E-mail: nkorogod@gmail.com

Новородовская Татьяна Сергеевна, доцент, кандидат биологических наук, доцент кафедры интеллектуальной собственности и управления проектами, Национальная металлур- 
гическая академия Украины (г. Днепр, Украина). ORCID ID: 0000-0002-4654-843X. E-mail: tetiana.novo@gmail.com

\section{ПРАКТИЧЕСКАЯ РЕАЛИЗАЦИЯ ПРОЕКТА СОЗДАНИЯ ОФИСА ТРАНСФЕРА ТЕХНОЛОГИЙ В ВЫСШИХ УЧЕБНЫХ ЗАВЕДЕНИЯХ}

Цель - обоснование необходимости создания офиса трансфера технологий в высшем учебном заведении, а именно в Национальной металлургической академии Украины, а также описание основных этапов практической реализации проекта создания офиса трансфера технологий в Национальной металлургической академии Украины на основе предложенных автором моделей и методов управления таким проектом.

Методика. Во время выполнения исследования были использованы: концептуальная модель управления проектом создания офиса трансфера технологий в высшем учебном заведении, которая учитывает специфику функционирования высшего учебного заведения и включает семь этапов создания офиса трансфера технологий; метод создания офиса трансфера технологий в высшем учебном заведении с элементами дизайн-мышления, предусматривающий определение потребностей и заинтересованности стейкхолдеров проекта в налаживании сотрудничества между представителями высшего учебного заведения и бизнеса и создания продукта проекта с учетом выявленных потребностей с применением инструментов дизайн-мышления.

Результаты. Исследование практической реализации проекта создания офиса трансфера технологий в высшем учебном заведении показало, что эффективность реализации такого проекта заключается прежде всего в применении проектного подхода. Применение концептуальной модели управления проектом создания офиса трансфера технологий в высшем учебном заведении и метода создания офиса трансфера технологий в высшем учебном заведении с элементами дизайн-мышления позволило наладить процесс создания данной организационной структуры в Национальной металлургической академии Украины, реализовать проект вовремя, в рамках запланированного бюджета и в соответствии с потребностями стейкхолдеров.

Научная новизна. Проведенные исследования доказали необходимость создания офиса трансфера технологий в Национальной металлургической академии Украины. Были описаны основные этапы реализации проекта создания офиса трансфера технологий в Национальной металлургической академии Украины, определены стейкхолдеры проекта, приведены основные положения Заявки на рассмотрение инициативы, которая включает цели проекта.

Практическая ценность. Описанные в данной статье основные этапы проекта создания офиса трансфера технологий в Национальной металлургической академии Украины в соответствии с концептуальной моделью управления проектом создания офиса трансфера технологий в высшем учебном заведении позволят создать такую организационную структуру на базе любого высшего учебного заведения.

Ключевые слова: офис трансфера технологий, проектный подход, концептуальная модель управления проектом, высшее учебное заведение, внедрение технологий.

Рукопис надійшов 29.05.2020 p. 